\title{
The osteoblast as an inflammatory cell: production of cytokines in response to bacteria and components of bacterial biofilms
}

\author{
Ulrike Dapunt ${ }^{*}$, Thomas Giese ${ }^{2}$, Sabine Stegmaier ${ }^{2}$, Arash Moghaddam ${ }^{3}$ and Gertrud Maria Hänsch²
}

\begin{abstract}
Background: Implant infections are a major complication in the field of orthopaedics. Bacteria attach to the implant-surface and form biofilm-colonies which makes them difficult to treat. Not only immune cells exclusively respond to bacterial challenges, but also local tissue cells are capable of participating in defense mechanisms. The aim of this study was to evaluate the role of osteoblasts in the context of implant infections.

Methods: Primary osteoblasts were cultivated and stimulated with free-swimming bacteria at $4{ }^{\circ} \mathrm{C}$ and $37{ }^{\circ} \mathrm{C}$. Supernatants were harvested for ELISA and expression of pro-inflammatory cytokines evaluated by RT-PCR. Bacterial binding to osteoblasts was evaluated using cytofluorometry and uptake was investigated by ${ }^{3} \mathrm{H}$ thymidine-labelling of bacteria. Osteoblasts were additionally stimulated with the extracellular polymeric substance (EPS) of Staphylococcus epidermidis biofilms, as well as components of the EPS; the bacterial heat shock protein GroEL in particular.

Results: We demonstrated that binding of bacteria to the osteoblast cell surface leads to an increased production of pro-inflammatory cytokines. Bacteria are capable of surviving intracellular. Furthermore, osteoblasts do not only respond to free-swimming, planktonic bacteria, but also to components of the EPS, including lipoteichoic acid and the heat shock protein GroEL.

Conclusion: In conclusion, local tissue cells, specifically osteoblasts, might contribute to the persistence of the inflammatory response associated with implant-infections.
\end{abstract}

Keywords: Osteoblast, Biofilm infection, GroEL, Extracellular polymeric substance

\section{Background}

Osteoblasts are primarily studied in the context of bone turnover and fracture healing. However, they can also acquire characteristics of inflammatory cells. For example, in response to bacterial challenge synthesis and release of pro-inflammatory cytokines is described, including generation of CXCL8 (interleukin 8, IL-8) or CCL2 (monocyte chemoattractant protein-1, MCP-1). Because both, CXCL8 and CCL2, attract leukocytes,

\footnotetext{
* Correspondence: Ulrike.Dapunt@med.uni-heidelberg.de

${ }^{1}$ Center for Orthopaedics, Trauma Surgery and Spinal Cord Injury, Heidelberg University Hospital, Schlierbacher Landstrasse 200a, Heidelberg 69118, Germany

Full list of author information is available at the end of the article
}

the local inflammatory response might escalade [1-4] (for review see $[5,6]$ ). Of note, osteoblasts also acquire properties of antigen presenting cells. Following uptake of Staphylococcus aureus, expression of MHC class II molecules and of co-stimulatory receptors was described [7, 8], as was the ability of MHC class II positive osteoblasts to present superantigens to $\mathrm{T}$ lymphocytes. Furthermore, osteoblasts produce defensin, a molecule with bactericidal activity that was initially described in leukocytes [9].

Osteoblasts take up bacteria by an active process $[10,11]$. Whether this uptake is a host defence reaction, analogous to the bacteriophagocytosis by leukocytes is still an open question. Under experimental 
conditions, ingested bacteria survive within the cell, leading to the notion that the osteoblast might provide a safe hiding place, which - in consequence - might contribute to the persistence of an infection [12-16].

Interactions of bacteria, either with phagocytic cells or osteoblasts, are mainly studied with free-swimming, planktonic bacteria. However, this is not the only lifestyle of bacteria, and possibly not even the preferred one, which was recognised over the last few years. Rather, many bacteria species live in structured colonies, embedded in an extracellular polymeric substance, socalled "biofilms" [17-20]. By means of biofilm formation, opportunistic bacteria in particular may acquire a pathogenic potential.

Our research group is particularly interested in infections due to biofilm formation on orthopaedic implants. In these infections, staphylococci species are prevalent [21]. Extensive inflammation around the implant occurs, which eventually results in bone degradation and in loosening of the prosthesis. Analysis of the local host response revealed infiltration of phagocytic cells, particularly of neutrophils, generation of pro-inflammatory cytokines and increased development of bone-resorbing osteoclasts [22-24].

A likely source for these cytokines are infiltrating neutrophils, which are activated by bacterial biofilms. Of note, entities within the extracellular substance of the biofilm activate neutrophils, among those peptidoglycan, lipoteichoic acid and the bacterial heat shock protein GroEL [25, 26]. Another source could be osteoblasts, which are also known to produce cytokines after appropriate stimulation [3-5]. We now addressed the question whether osteoblasts are not only activated by planktonic staphylococci, but by entities derived from bacterial biofilms.

\section{Methods}

\section{Culture of osteoblasts}

Primary osteoblasts were cultivated from human bone marrow which was harvested either from the femoral bone using the RIA (reamer-irrigator-aspirator)-technique or from the iliac crest of patients undergoing surgery due to fracture malunion or non-union, and who required an autologous bone graft. Informed consent was obtained from the patients, and the study was approved by the local ethic committee of Heidelberg University (S-355/2010; October 28th 2010). Samples were grinded using sterile scalpels and cultivated in osteoblast growth medium (PromoCell, Heidelberg, Germany) containing $0.1 \%$ penicillin/streptomycin (Gibco Life Technologies, Eggenstein, Germany). Outgrowth of cells occurred usually between 4 to 8 days. Cells were subcultivated following digestion with trypsin (0.05\% Trypsin-EDTA, Life Technologies) for $5 \mathrm{~min}$ at
$37{ }^{\circ} \mathrm{C}$ and resuspended in osteoblast growth medium. After 10 to 14 days, homogenous cell layers were seen; osteoblasts were identified by expression of collagen type I and bone sialoglycoprotein, and lack of markers for myeloid cells (CD11b, CD68) (all from Beckman Coulter, Krefeld, Germany) as seen by laser scan microscopy and by cytofluorometry of detached cells. Expression of CD90 (Beckman Coulter, Krefeld, Germany) was used as a marker for de-differentiation. Osteoblasts were used for a maximum of two passages and experiments were carried out in 6 or 24-well dishes (NuncTM, Wiesbaden, Germany) at a concentration of $2 \times 10^{5}$ cells $/ \mathrm{mL}$ in osteoblast growth medium.

\section{Cytofluorometry and microscopy}

Cytofluorometry was performed with paraformaldehydefixed osteoblasts using FACS Calibur and Cell quest pro as software (Becton and Dickinson, Heidelberg, Germany). Presence of collagen type I and bone sialoglycoprotein was assessed by indirect immunofluorescence. Slides were viewed by Laser scan microscopy (LSM, Leica).

\section{Stimulation of osteoblasts by bacteria}

Staphylococcus aureus (Seattle 1945, ATCC 25923, Wesel, Germany) and Staphylococcus epidermidis (RP62a, ATCC 35984) were grown overnight on a blood agar plate at $37{ }^{\circ} \mathrm{C}$ (number PB5039A, Thermo Scientific, Germany, Wesel). The following day, bacteria were scraped of the plate, suspended in phosphate buffered saline and adjusted to $1 \times 10^{8}$ cells $/ \mathrm{mL}$. Bacteria were added in a ratio of 1:20, 1:100 and 1:500 bacteria per osteoblast $\left(2 \times 10^{5}\right.$ cells per well in a 6 -well culture dish in a volume of $4 \mathrm{~mL}$ ) and incubated at either $4{ }^{\circ} \mathrm{C}$ or $37{ }^{\circ} \mathrm{C}$ for the times indicated in the respective experiments (two different temperatures were compared, because phagocytosis is impaired at $4{ }^{\circ} \mathrm{C}$ ). The supernatant was discarded and $1600 \mu \mathrm{g}$ vancomycin $/ 4 \mathrm{~mL}$ osteoblast growth medium was added for $30 \mathrm{~min}$. The supernatant was discarded and replaced with $4 \mathrm{~mL}$ osteoblast growth medium containing $80 \mu \mathrm{g}$ vancomycin and culture was continued for the times indicated in the respective experiment. In another set of experiments, heparin $200 \mu \mathrm{g}$ (Heparin Sodium 25000, Ratiopharm, Ulm, Germany) was added before stimulation with bacteria and preincubated at room temperature for $10 \mathrm{~min}$. After that, bacteria were added and experiments carried out as described above.

For RT-PCR analysis, cells were collected in $400 \mu \mathrm{L}$ lysis buffer from the MagnaPure mRNA Isolation Kit I containing $1 \%$ DTT (v/w) (ROCHE Applied Sciences RAS, Mannheim, Germany). To determine release of cytokines, culture was continued for $6 \mathrm{~h}, 24 \mathrm{~h}$ and $48 \mathrm{~h}$ at $37{ }^{\circ} \mathrm{C}$. Supernatants were then harvested and stored at $-20{ }^{\circ} \mathrm{C}$ for ELISA (see below). 


\section{Binding of bacteria to osteoblasts}

FITC-labelled dead S. aureus were purchased (Molecular probes, S-2851, ThermoFisher Scientific, Schwerte, Germany). S. epidermidis were labelled with fluorescein isothiocyanate (FITC) according to the following protocol: FITC isomer I was purchased (Sigma- Aldrich, Darmstadt, Germany; F7250). A 5 mg/mL DMSO stock solution was diluted in phosphate buffered saline 1:10 (end concentration $0.5 \mathrm{mg} / \mathrm{mL}$ ) and was incubated with bacteria $\left(8 \times 10^{7}\right)$ for $45 \mathrm{~min}$ at $37^{\circ} \mathrm{C}$. Following repeated washing, the bacteria were suspended in $4 \%$ formaldehyde. FITC-labelling of bacteria was evaluated by cytofluorometry. Binding of FITC-labeled bacteria to osteoblasts was determined by incubating with bacteria at a ratio of 1:100 bacteria per osteoblast for $2 \mathrm{~h}$ at either $37^{\circ} \mathrm{C}$ or $4{ }^{\circ} \mathrm{C}$, followed by cytofluorometry and by laser scan microscopy.

To visualise uptake of bacteria, osteoblasts were incubated with FITC-labelled bacteria (see below) at a ratio of 1:100 for $2 \mathrm{~h}$. The cells were fixed and viewed by LSM.

\section{Uptake of ${ }^{3} \mathrm{H}$ thymidine-labelled bacteria}

An overnight culture of $S$. epidermidis in trypticase soy broth was performed. The next morning $2 \mathrm{~mL}$ of the overnight culture were added to $20 \mathrm{~mL}$ fresh trypticase soy broth containing $100 \mu \mathrm{L}{ }^{3} \mathrm{H}$ Thymidin (Amersham, UK, TRA120 $1 \mathrm{mCi} / \mathrm{mL}$ ) and culture was continued for 4 h. Radioactivity associated with the bacteria was quantified. Osteoblasts were then incubated with the labelled bacteria as described above for $3 \mathrm{~h}$. Then cell-associated radioactivity was measured in an aliquot, the remaining cells were treated with vancomycin to kill adherent, but not internalised cells (as described above), then lysed. An aliquot of the lysate was placed onto agar plates, and colonies were counted after $24 \mathrm{~h}$.

\section{Formation of biofilms and extraction of the extracellular polymeric substance (EPS)}

S. epidermidis was added to $1.5 \mathrm{~L}$ of pre-warmed Trypticase Soy Broth (TSB) to reach a final concentration of $3 \times 10^{6} \mathrm{CFU} / \mathrm{mL}$, then transferred to 30 polysterol dishes (Nunc 150x20, Thermo Fisher Scientific, Roskilde, Denmark) with a final volume of $50 \mathrm{~mL}$ per dish. After incubation for 2 days at $37{ }^{\circ} \mathrm{C}$ without shaking, the medium was removed and the remaining biofilm was scrapped off. The following treatment was adapted from Liu et al. (2002) [27]: per $10 \mathrm{~mL}$ of slime, $60 \mu \mathrm{L}$ of $37 \%$ formaldehyde was added and mixed for $1 \mathrm{~h}$ at $4{ }^{\circ} \mathrm{C}$, followed by the addition of $4 \mathrm{~mL} 1 \mathrm{M} \mathrm{NaCl}$ and mixing for another $3 \mathrm{~h}$ at $4{ }^{\circ} \mathrm{C}$. The resulting suspension was then centrifuged (Sorvall 5B Plus) for $15 \mathrm{~min}$ $\left(18000 \mathrm{rpm}\right.$ at $\left.4{ }^{\circ} \mathrm{C}\right)$. The pellet was discarded, the supernatant filtrated (Millex Syringe-driven Filter Unit $0.22 \mathrm{um}$, Merck Milipore Ltd, Tullagreen, Ireland) and then dialysed overnight against Milipore water at $4{ }^{\circ} \mathrm{C}$ (membrane cut off $3600 \mathrm{Da}$; Spectrum Labs, Rancho Dominguez, CA, USA). The water was replaced and the isolated EPS was again dialysed for another $3 \mathrm{~h}$, then concentrated using Vivaspin 20 (Sartorius Stedim Biotech, Göttingen, Germany) to a final volume of $4 \mathrm{~mL}$ and frozen at $-20{ }^{\circ} \mathrm{C}$ until use. Extraction of EPS from 1.79 square meters biofilm yielded on average $44.9 \mathrm{mg}$ of protein.

To detect possible endotoxin contamination a limulus assay was performed (Pierce LAL Chromogenic Endotoxin Quantitation Kit, Thermo Scientific, Bonn, Germany) following the instructions provided by the manufacturer. The adsorption of LPS was accomplished using Pierce High Capacity Endotoxin Removal Spin Column following the instructions provided but adjusting the incubation time to $2 \mathrm{~h}$ in order to maximize LPS-removal.

\section{Stimulation of osteoblasts}

LTA (Sigma Aldrich) and recombinant GroEL (Enzo Life Sciences) were purchased. Osteoblasts were cultivated with LTA1 or LTA5 $(1 \mu \mathrm{g} / \mathrm{mL}$ and $5 \mu \mathrm{g} / \mathrm{mL}$, respectively), GroEL1 and GroEL5 $(1 \mu \mathrm{g} / \mathrm{mL}$ and $5 \mu \mathrm{g} / \mathrm{mL}$, respectively) or EPS2 and EPS10 (2\% and $10 \%(\mathrm{v} / \mathrm{v}))$. Supernatants were collected after $6 \mathrm{~h}$ and $24 \mathrm{~h}$ incubation time at $37{ }^{\circ} \mathrm{C}$ and cells were collected in lysis buffer for RT-PCR-analysis (see below).

\section{Quantitative real-time polymerase chain reaction}

Cells were collected in $400 \mu \mathrm{L}$ lysis buffer from the MagnaPure mRNA Isolation Kit I containing $1 \%$ DTT (v/w) (ROCHE Applied Sciences - RAS, Mannheim). mRNA was isolated with the MagnaPure-LC device using the mRNA-I standard protocol. An aliquot was reversely transcribed using AMV-RT and oligo-(dT) as primer (First Strand cDNA synthesis kit, Roche) according to the manufactures protocol in a thermocycler. Primer sets optimized for the LightCycler (RAS, Mannheim Germany) were developed and purchased from SEARCH-LC GmbH (www.Search-LC.com). The PCR was performed with the LightCycler ${ }^{\circ}$ FastStart DNA Sybr GreenI kit (RAS) according to the protocol provided in the parameter specific kits. To control for specificity of the amplification products, a melting curve analysis was performed. The copy number was calculated from a standard curve, obtained by plotting known input concentrations of four different plasmids at log dilutions to the PCR-cycle number (CP) at which the detected fluorescence intensity reaches a fixed value. To correct for differences in the content of mRNA, the calculated transcript numbers were normalized according to the expression of the housekeeping gene peptidylprolyl isomerase B (PPIB). Values were thus given as transcripts per 1000 transcripts of PPIB. 
ELISA

IL-8, IL-6 and CCL2 in cell culture supernatants were determined using commercially available ELISA kits according to the protocol provided by the manufacturer. The human Elisa kits were purchased from R\& D Systems (Minneapolis, USA).

\section{Statistical analysis}

Differences between groups were calculated using ANOVA one-way or Mann-Whitney test using Origin 9.0 software. Significance level was determined as $P<0.05$.

\section{Results}

\section{Osteoblasts in culture}

Numerous methods are available to raise osteoblasts from bone marrow. Under our culture conditions and with use of a special medium that prevented growth of fibroblasts, homogenous cultures were obtained within 10-14 days. Characteristic for osteoblasts is the production of type I collagen and of bone sialoglycoprotein (examples in Fig. 1a-e) and lack of markers for myeloid cells (CD11b, CD68) (data not shown). Under culture conditions, osteoblasts undergo a dedifferentiation, which can be followed up by the acquisition of the surface protein CD90, the expression of which increased steadily with time in culture, or number of passage, respectively (Fig. 1f). For our experiments we used cells in passage 1 and 2, only. Cells derived from different donors varied somewhat with regard to their response to bacterial challenges, which explains the wide variation seen in some of the experiments.

\section{Phagocytosis of bacteria and release of cytokines}

To assess binding and uptake of bacteria, osteoblasts were cultivated with FITC-labelled S. epidermidis or $S$. aureus, respectively. At $4{ }^{\circ} \mathrm{C}$, binding and association of bacteria with osteoblasts was seen by cytofluorometry
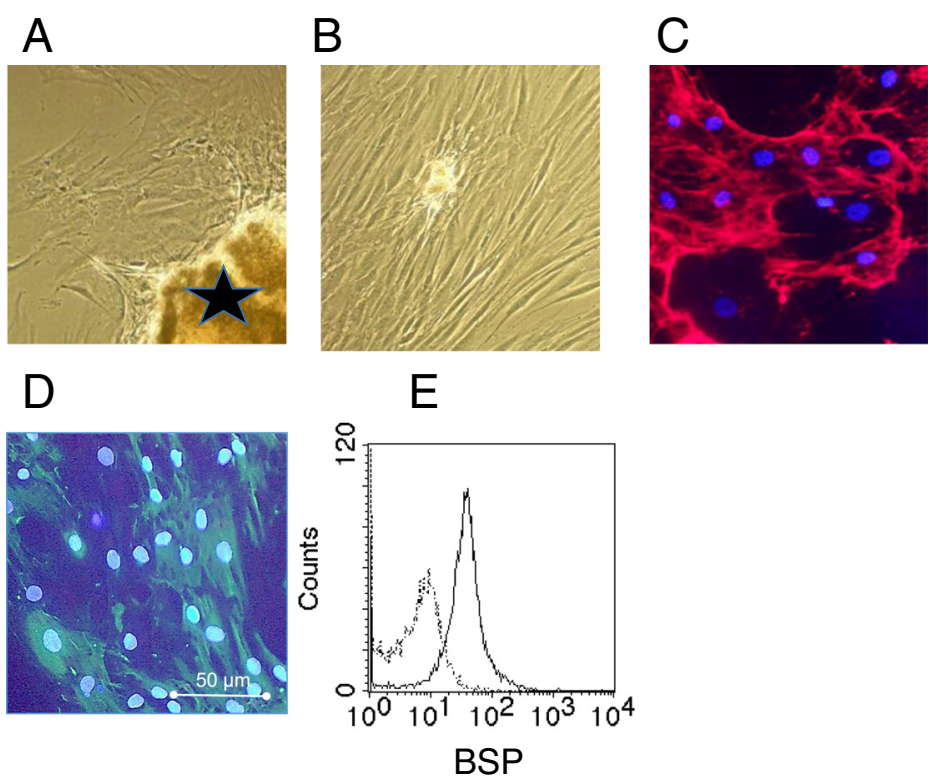

$F$

P2

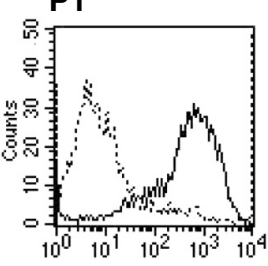

MFI:

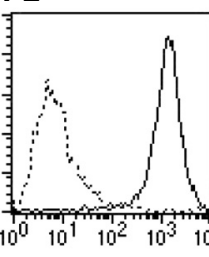

P3

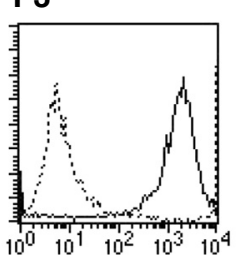

P4

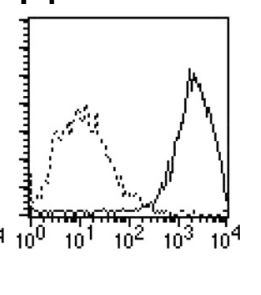

CD90

1883

1914

Fig. 1 Culture and characterization of osteoblasts: Bone marrow was shredded and cultivated. a Osteoblasts started growing and after 10-14 days (the asterix indicates bone); b a near confluent layer of homogenous cells was obtained. c The cells produced collagen type I (stained in red; nuclei in blue); and $\mathbf{d}$ bone sialoglycoprotein (BSP) (stained in green) as seen by laser scan microscopy and $\mathbf{e}$ by cytofluorometry of detached cells (thick line; the thin line shows the isotype control). f The osteoblasts in early passage express CD90 (thick line; the thin line shows the isotype control); expression increases with time in culture and passage number as seen by an increase of the mean fluorescence intensity (MFI) 


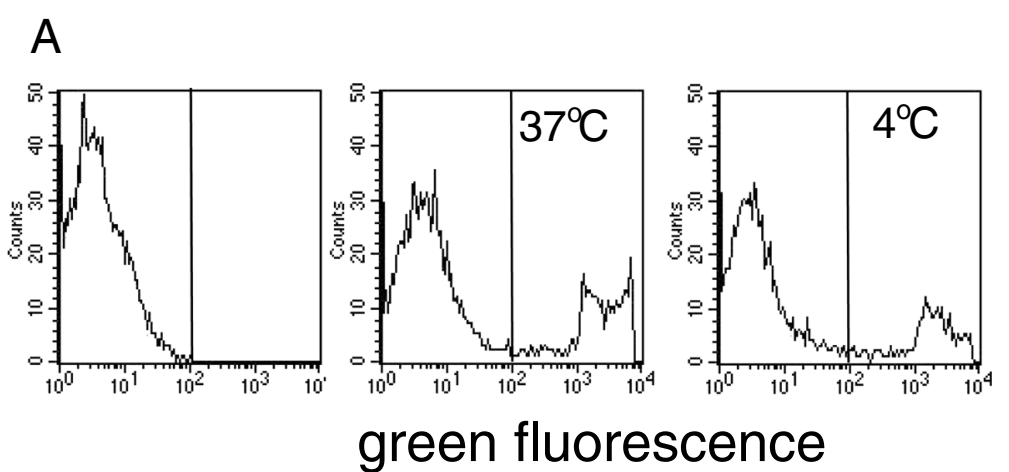

B

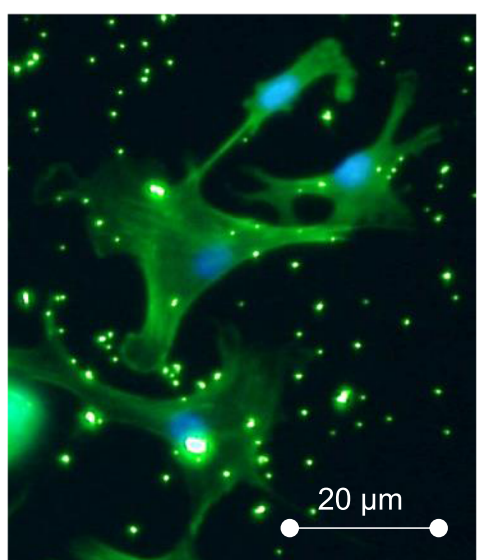

Fig. 2 Binding and uptake of S. aureus to osteoblasts: a Osteoblasts were incubated with FITC-labelled bacteria at either $37^{\circ} \mathrm{C}$ or $4{ }^{\circ} \mathrm{C}$. Then fluorescence associated with the cells was determined (the very left panel shows the autofluorescence of the cells). $\mathbf{b}$ Binding and uptake of bacteria could be confirmed by laser scan microscopy (bacteria in green; nuclei in blue)

and laser scan microscopy, respectively (Fig. 2a, b). The data were confirmed with ${ }^{3} \mathrm{H}$-thymidine-labelled bacteria. Following incubation for $3 \mathrm{~h}$ at $37^{\circ} \mathrm{C}$ or $4{ }^{\circ} \mathrm{C}$, cell-associated radioactivity was measured, and was found to be similar at the two temperatures. Binding could be inhibited by heparin (on average by $30 \%$ ) as reported before by others [28] (Table 1). To determine uptake of bacteria, again ${ }^{3} \mathrm{H}$-thymidine-labelled bacteria were used. Following incubation with osteoblasts for $3 \mathrm{~h}$ at either $4{ }^{\circ} \mathrm{C}$ or $37^{\circ} \mathrm{C}$, the cells were treated with vancomycin to kill adherent, but not internalised cells; then cell lysates were prepared and spread onto agar plates. After $24 \mathrm{~h}$, bacteria colonies were counted as indicator of internalised bacteria. As seen in Table 1, internalisation occurred at $37^{\circ} \mathrm{C}$, but not at $4{ }^{\circ} \mathrm{C}$ (data summarised in Table 1 ).
In a next set of experiments effects on cytokine release in response to bacteria was measured. When osteoblasts were exposed to live bacteria, an increase in mRNA of IL-6, IL-8 and CCL2 was observed (Fig. 3a), and after prolonged incubation also release into the surrounding medium. IL-8 release was delayed compared to release of CCL2 (Fig. 3b, c). The absolute concentrations of cytokines varied widely when cells of different donors were compared. In all experiments, however, exposure to bacteria increased the concentration of IL-6, IL-8 or CCL2. On a given bacteria-to-osteoblast ratio, S. epidermidis apparently induced more cytokines compared to $S$. aureus, although due to the wide variation of responses, a categorical difference cannot be deduced (Fig. 3d). Of note, initial contact of osteoblasts with

Table 1 Phagocytosis of live bacteria

\begin{tabular}{|c|c|c|c|c|}
\hline & \multicolumn{2}{|c|}{ bacteria associated with cells (\% of input) (mean of $n=4$ ) } & \multicolumn{2}{|c|}{ colonies counted after $24 \mathrm{~h}$} \\
\hline & $37^{\circ} \mathrm{C}$ & $4^{\circ} \mathrm{C}$ & $37^{\circ} \mathrm{C}$ & $4^{\circ} \mathrm{C}$ \\
\hline osteoblasts + S. epidermidis & $47 \pm 15$ & $51 \pm 21$ & $257 ; 65^{*}$ & $52 ; 14^{*}$ \\
\hline osteoblasts + heparin + S.epidermidis & $39 \pm 21$ & $34 \pm 12$ & $67 ; 38^{*}$ & $7 ; 8^{*}$ \\
\hline
\end{tabular}

*The values represent each the mean of duplicates; two independent experiments are shown 
A

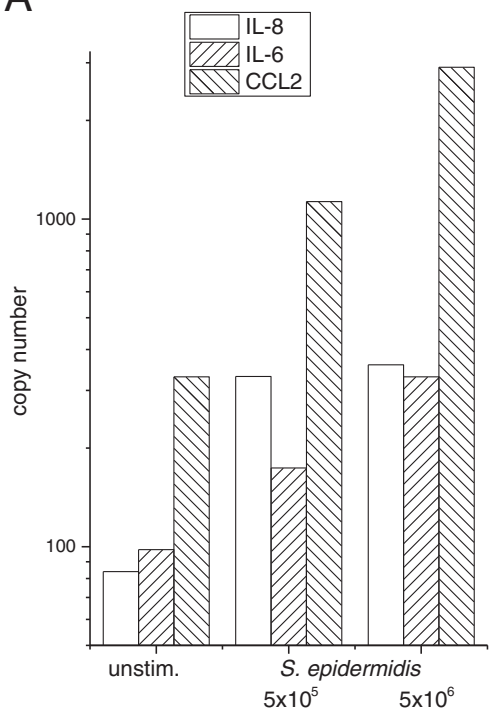

C

cytokine release (ng/mi)
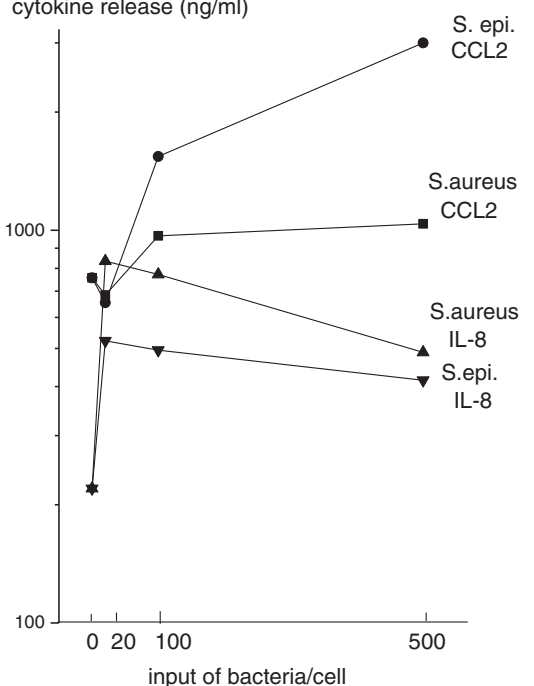

B

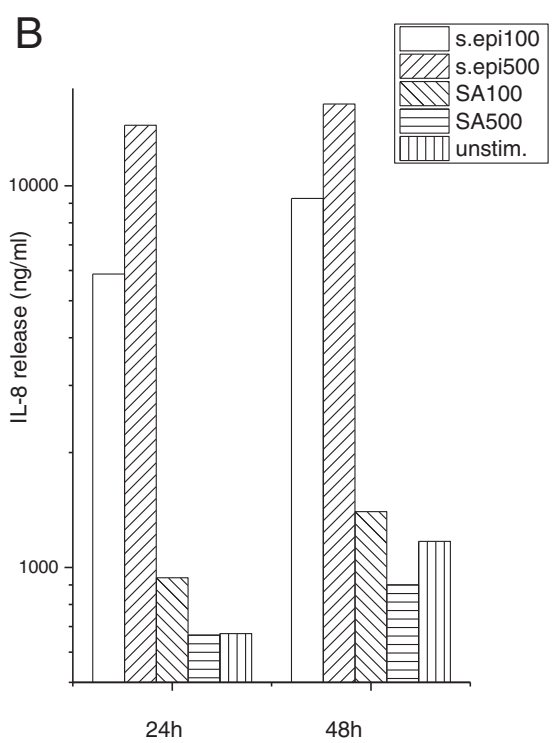

D

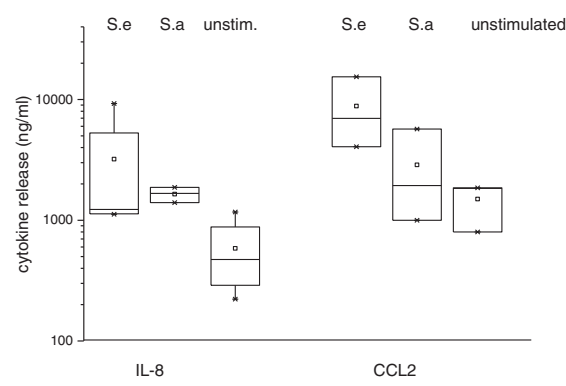

$E$

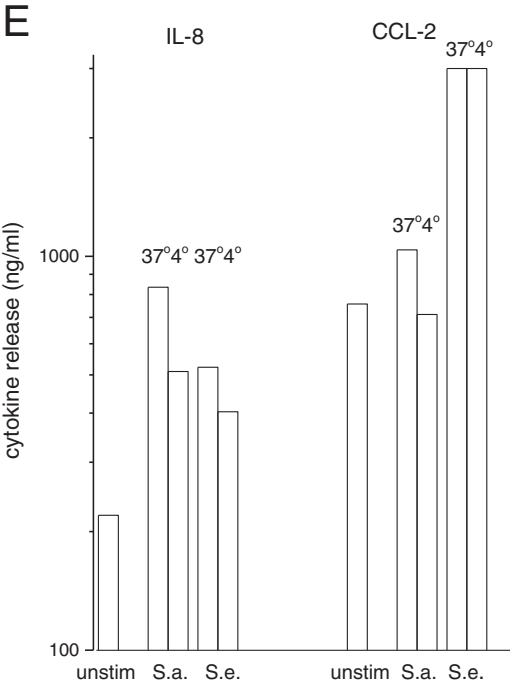

Fig. 3 (See legend on next page.) 
(See figure on previous page.)

Fig. 3 Cytokine production and release in response to bacteria: a Osteoblasts were cultivated with S. epidermidis in two concentrations and after 6 h, RNA for IL-6, IL-8, and CCL2 was quantified (data with cells of one individual are shown; mean of duplicates). Cytokine release into the supernatant was determined $24 \mathrm{~h}$ and $48 \mathrm{~h}$ after exposure to either S. aureus or S. epidermidis (bacteria to cell ratio 100 or 500 bacteria/per cell) (b) or (c) with a ratio of 1:20;100 or 500 (data with cells of one individual are shown). $\mathbf{d}$ shows the summary of experiments with cells of 5 individuals stimulated with bacteria (1:100) for $24 \mathrm{~h}$. e osteoblasts were cultivated with bacteria $(1: 100)$ at either $4{ }^{\circ} \mathrm{C}$ or $37^{\circ} \mathrm{C}$ for 20 min; after washing culture was continued for $24 \mathrm{~h}$ and cytokines in the supernatant were measured

bacteria at $4{ }^{\circ} \mathrm{C}$, which results in binding but not in uptake, was sufficient to induce cytokine synthesis (Fig. 3e).

\section{Effects of extracellular biofilm substance on osteoblasts}

To gain information on effects of bacterial biofilms on osteoblasts, soluble entities of the extracellular polymeric substance (EPS) of biofilms were prepared. EPS consists mainly of water, a variety of glycoproteins and complex carbohydrates, lipids, and bacterial DNA. Total EPS when added in high concentration $(10 \%(\mathrm{v} / \mathrm{v}))$ was toxic for the osteoblasts, lower concentrations of $2 \%$ induced synthesis of IL-8, IL-6, and CCL2 (Fig. 4a). Precipitating proteins from the EPS revealed that both, the precipitated protein fraction, as well as the remaining non-precipitable fraction contained activating entities. A reasonable good candidate for the non-precipitable entity is lipoteichoic acid (LTA); and indeed, we could demonstrate an activation of cytokine synthesis and release by LTA (data summarised in Fig. 4a). We further tested the bacterial heat shock protein GroEL, which is present in the protein fraction of EPS. GroEL induced IL-6, IL- 8 and CCL2 release within 6 to 24 h. Again, the responsiveness varied among donors, and again, release of IL-8 was somewhat prolonged compared to CCL2 (Fig. 4a-f). The effect on IL-8 induction was also small, but conspicuous when directly comparing unstimulated cells with cells exposed to GroEL derived from the same individual (data summarised in Fig. 4c).

\section{Discussion}

Implant-associated infections are a feared complication in the field of orthopaedics, since these infections are difficult to diagnose and usually require prolonged treatment [29-31]. The reason for these difficulties is ascribed to the fact that bacteria attach to an implant surface, produce and embed themselves in an extracellular polymeric substance and are thus capable of forming biofilm-colonies that are resistant to antibiotic treatment (reviewed in $[17-19,32,33]$ ). Moreover, it has been proposed that bacteria in biofilms are protected from the immune system; the latter even being incapable of recognising biofilms [34-36].

However, given the fact that biofilm-formation is actually the preferred and thus probably predominant living-form of bacteria, makes it unlikely that the immune system does not respond to these infections. In support of this theory it has been shown that immune cells infiltrate areas of biofilm formation and attack biofilms [22, 37]. Of note, phagocytic cells recognize biofilms even without opsonisation; a process which is required for recognition and phagocytosis of free-swimming bacteria [38, 39]. Indeed, neutrophils were activated by the eluted extracellular matrix, and more recently, we identified lipoteichoic acid (LTA) and the bacterial heat shock protein GroEL as activating entities within the biofilm matrix [26]. In neutrophils, GroEL leads to an up-regulation of activation-associated markers on the cell surface and increased oxygen radical production [26].

Since neutrophils are not necessarily the first cells to encounter a biofilm infection, we now evaluated the effects of the extracellular polymeric substance, LTA, and GroEL on local tissue cells, namely osteoblasts. We were able to demonstrate that osteoblasts responded by an increased production of proinflammatory cytokines which in turn can attract immuno-competent cells, and might thus initiate or perpetuate the defence against biofilm infections. That osteoblasts produce cytokines in response to inflammatory stimuli has been reported before by others [4]; the novel aspect of our study is, that bacteriaderived entities and by implication bacterial biofilms activate the inflammatory potential of osteoblasts, most likely as the first reaction to an infection.

Another interesting aspect of osteoblast-bacteria interaction is the uptake of bacteria by osteoblasts and the intracellular survival of bacteria. In extension of previous studies by others [3, 28, 40] we found that the contact of bacteria with the osteoblast is sufficient to induce cytokine induction. Moreover, in line with data by others, this effect could be inhibited by heparin, which interacts with fibronectin-binding; the latter being essential for internalization of bacteria $[28,41]$. We also demonstrated that bacteria are capable of intracellular survival in osteoblasts which might offer a feasible explanation of persisting and recurring bone infections. These findings are in line with our previous findings on enhanced cytokine expression in the tissue surrounding an infected implant which might be generated not merely by infiltrating leukocytes, but also local tissue cells [24, 42, 43]. 


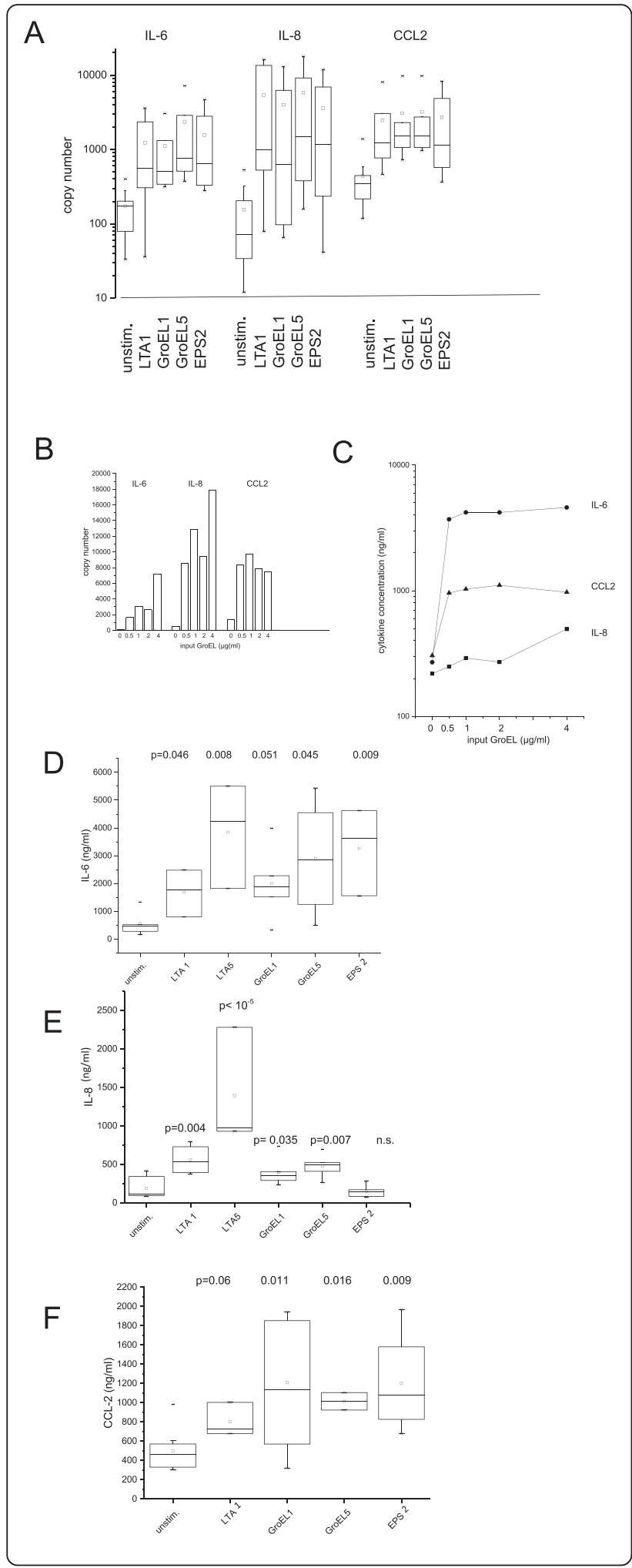

Fig. 4 Cytokine production and release in response to bacterial biofilm EPS or EPS-derived materials: a Osteoblasts were cultivated for $6 \mathrm{~h}$ with either LTA1 $(1 \mu \mathrm{g} / \mathrm{mL})$, GroEL1 or GroEL5 (1 and $5 \mu \mathrm{g} / \mathrm{mL}$, respectively), or EPS2 (2\% (v/v)) extracted from S. epidermidis biofilms; then cytokine production was determined by quantitative RT-PCR (data of 5 individuals are summarized). $\mathbf{b}$ and $\mathbf{c}$ show a dose-response curve for GroEL with cells from one individual (mean of duplicates); RT-PCR was performed after $6 \mathrm{~h}$ in culture, release into the supernatant after 24 h. $\mathbf{d}-\mathbf{f}$ show the summary of experiments with cells of 5-7 individuals. Cytokines were measured in the cell-free supernatant after $24 \mathrm{~h}$ stimulation with LTA1 and LTA5 (1 and $5 \mu \mathrm{g} / \mathrm{mL}$, respectively) (for CCL2, only LTA1 was measured), GroEL1 and GroEL5 (1 and $5 \mu \mathrm{g} / \mathrm{mL}$, respectively) or EPS2 (2\% (v/v))

\section{Conclusion}

In conclusion, we were able to show that aside from the obvious role of osteoblasts in bone formation, they also respond to bacterial infections. Osteoblasts are capable of increased expression and release of pro-inflammatory cytokines when challenged with free-swimming bacteria. Furthermore, we demonstrated internalization of bacteria and intracellular survival as a method of bacterial persistence leading to chronic infectious disease.

Osteoblasts not only respond to free-swimming bacteria, but also to components of the extracellular polymeric substance, among them the bacterial heat shock protein GroEL, and may therefore be critically involved in defence mechanisms against biofilm infections.

\section{Abbreviations}

CCL2, monocyte chemotactic protein 1 (MCP1a); EPS, extracellular polymeric substance; IL-6, Interleukin-6; IL-8, Interleukin-8; LTA, lipoteichoic acid; qRT-PCR, quantitative real-time polymerase chain reaction.

\section{Acknowledgements}

The authors declare no conflict of interest.

Dr. Ulrike Dapunt was supported by the Olympia-Morata-Scholarship of the

Faculty of Medicine of Heidelberg University.

\section{Authors' contribution}

All authors have made substantial contributions to conception and design, acquisition of data, analysis and interpretation of data and have been involved in drafting the manuscript or revising it critically for important intellectual content. All authors have given final approval of the version to be published and agree to be accountable for all aspects of the work in ensuring that questions related to the accuracy or integrity of any part of the work are appropriately investigated and resolved.

\section{Competing interests}

The authors declare that they have no competing interests.

\section{Ethics approval and consent to participate}

Informed and written consent was obtained from the patients, and the study was approved by the local ethic committee of Heidelberg University.

\section{Author details}

${ }^{1}$ Center for Orthopaedics, Trauma Surgery and Spinal Cord Injury, Heidelberg University Hospital, Schlierbacher Landstrasse 200a, Heidelberg 69118, Germany. ${ }^{2}$ Institute for Immunology, Heidelberg University, Im Neuenheimer Feld 305, Heidelberg 69120, Germany. ${ }^{3}$ HTRG Heidelberg Trauma Research Group, Center for Orthopaedics, Trauma Surgery and Spinal Cord Injury, Heidelberg University Hospital, Schlierbacher Landstrasse 200a, Heidelberg 69118, Germany. 


\section{Received: 18 December 2015 Accepted: 19 May 2016}

Published online: 02 June 2016

\section{References}

1. Littlewood AJ, Russell J, Harvey GR, Hughes DE, Russell RG, Gowen M. The modulation of the expression of IL-6 and its receptor in human osteoblasts in vitro. Endocrinology. 1991;129(3):1513-20.

2. Littlewood AJ, Aarden LA, Evans DB, Russell RG, Gowen M. Human osteoblastlike cells do not respond to interleukin-6. J Bone Miner Res. 1991;6(2):141-8.

3. Bost KL, Ramp WK, Nicholson NC, Bento JL, Marriott I, Hudson MC Staphylococcus aureus infection of mouse or human osteoblasts induces high levels of interleukin-6 and interleukin-12 production. J Infect Dis. 1999; 180(6):1912-20.

4. Marriott I, Gray DL, Tranguch SL, Fowler Jr VG, Stryjewski M, Scott Levin L, Hudson MC, Bost KL. Osteoblasts express the inflammatory cytokine interleukin- 6 in a murine model of Staphylococcus aureus osteomyelitis and infected human bone tissue. Am J Pathol. 2004;164(4):1399-406.

5. Marriott I. Osteoblast responses to bacterial pathogens: a previously unappreciated role for bone-forming cells in host defense and disease progression. Immunol Res. 2004;30(3):291-308.

6. Shi S, Zhang X. Interaction of Staphylococcus aureus with osteoblasts (Review). Exp Ther Med. 2012;3(3):367-70.

7. Schrum LW, Bost KL, Hudson MC, Marriott I. Bacterial infection induces expression of functional MHC class II molecules in murine and human osteoblasts. Bone. 2003:33(5):812-21.

8. Schrum LW, Marriott I, Butler BR, Thomas EK, Hudson MC, Bost KL. Functional CD40 expression induced following bacterial infection of mouse and human osteoblasts. Infect Immun. 2003;71(3):1209-16.

9. Warnke PH, Springer IN, Russo PA, Wiltfang J, Essig H, Kosmahl M, Sherry E, Acil Y. Innate immunity in human bone. Bone. 2006;38(3):400-8.

10. Hudson MC, Ramp WK, Nicholson NC, Williams AS, Nousiainen MT. Internalization of Staphylococcus aureus by cultured osteoblasts. Microb Pathog. 1995;19(6):409-19.

11. Ellington JK, Reilly SS, Ramp WK, Smeltzer MS, Kellam JF, Hudson MC. Mechanisms of Staphylococcus aureus invasion of cultured osteoblasts. Microb Pathog. 1999;26(6):317-23.

12. Bayles KW, Wesson CA, Liou LE, Fox LK, Bohach GA, Trumble WR. Intracellular Staphylococcus aureus escapes the endosome and induces apoptosis in epithelial cells. Infect Immun. 1998;66(1):336-42.

13. Mohamed W, Sommer U, Sethi S, Domann E, Thormann U, Schutz I, Lips KS, Chakraborty $T$, Schnettler R, Alt V. Intracellular proliferation of $S$. aureus in osteoblasts and effects of rifampicin and gentamicin on S. aureus intracellular proliferation and survival. Eur Cell Mater. 2014:28:258-68.

14. Loffler B, Tuchscherr L, Niemann S, Peters G. Staphylococcus aureus persistence in non-professional phagocytes. Int J Med Microbiol. 2014 304(2):170-6.

15. Tuchscherr L, Medina E, Hussain M, Volker W, Heitmann V, Niemann S, Holzinger D, Roth J, Proctor RA, Becker $\mathrm{K}$ et al. Staphylococcus aureus phenotype switching: an effective bacterial strategy to escape host immune response and establish a chronic infection. EMBO Mol Med. 2011;3(3):129-41.

16. Valour F, Rasigade JP, Trouillet-Assant S, Gagnaire J, Bouaziz A, Karsenty J, Lacour C, Bes M, Lustig S, Benet T et al. Delta-toxin production deficiency in Staphylococcus aureus: a diagnostic marker of bone and joint infection chronicity linked with osteoblast invasion and biofilm formation. Clin Microbiol Infect. 2015;21(6):568 e561-511.

17. Costerton JW. Introduction to biofilm. Int J Antimicrob Agents. 1999;1 1(3-4): 217-21. discussion 237-219.

18. Costerton JW, Stewart PS, Greenberg EP. Bacterial biofilms: a common cause of persistent infections. Science. 1999;284(5418):1318-22.

19. Costerton W, Veeh R, Shirtliff M, Pasmore M, Post C, Ehrlich G. The application of biofilm science to the study and control of chronic bacterial infections. J Clin Invest. 2003;112(10):1466-77.

20. Parsek MR, Singh PK. Bacterial biofilms: an emerging link to disease pathogenesis. Annu Rev Microbiol. 2003:57:677-701.

21. Arciola CR. Opportunistic bacteria in implant infections. Knowing them to plan their control. Int J Artif Organs. 2006:29(4):341-2.

22. Wagner C, Kondella K, Bernschneider T, Heppert V, Wentzensen A, Hansch GM. Post-traumatic osteomyelitis: analysis of inflammatory cells recruited into the site of infection. Shock. 2003;20(6):503-10.
23. Gaida MM, Stegmaier S, Schirmacher P, Wagner C, Hänsch GM. Polymorphonuclear neutrophils in osteomyelitis: link to osteoclast generation and bone resorption. Eur J Inflamm. 2012;10(3):413-26.

24. Dapunt U, Giese T, Lasitschka F, Lehner B, Ewerbeck V, Hansch GM. Osteoclast generation and cytokine profile at prosthetic interfaces: a study on tissue of patients with aseptic loosening or implant-associated infections. Eur J Inflamm. 2014;12(1):147-59.

25. Meyle E, Brenner-Weiss G, Obst U, Prior B, Hansch GM. Immune defense against $\mathrm{S}$. epidermidis biofilms: components of the extracellular polymeric substance activate distinct bactericidal mechanisms of phagocytic cells. Int J Artif Organs. 2012;35(10):700-12.

26. Maurer S, Meyle E, Prior B, Hänsch GM, Dapunt U. Activation of Neutrophils by the extracellular polymeric substance of Sepidermidis biofilms is mediated by the bacterial heat shock protein Groel. J Biotechnol Biomater. 2015:5(1):176-83.

27. Liu H, Fang HH. Extraction of extracellular polymeric substances (EPS) of sludges. J Biotechnol. 2002;95(3):249-56.

28. Arciola CR, Bustanji Y, Conti M, Campoccia D, Baldassarri L, Samori B, Montanaro L. Staphylococcus epidermidis-fibronectin binding and its inhibition by heparin. Biomaterials. 2003;24(18):3013-9.

29. Haenle M, Skripitz C, Mittelmeier W, Skripitz R: Economic impact of infected knee arthroplasty. Scie World J. 2012;2012(196515):6. doi:10.1100/2012/ 196515

30. Poultsides $L A$, Liaropoulos $L L$, Malizos KN. The socioeconomic impact of musculoskeletal infections. J Bone Joint Surg Am. 2010;92(11):e13.

31. Tsukayama DT. Pathophysiology of posttraumatic osteomyelitis. Clin Orthop Relat Res. 1999;360:22-9.

32. Hall-Stoodley L, Stoodley P. Evolving concepts in biofilm infections. Cell Microbiol. 2009;11(7):1034-43.

33. Arciola CR, Alvi FI, An YH, Campoccia D, Montanaro L. Implant infection and infection resistant materials: a mini review. Int J Artif Organs. 2005;28(11): 1119-25.

34. Schommer NN, Christner M, Hentschke M, Ruckdeschel K, Aepfelbacher M, Rohde H. Staphylococcus epidermidis uses distinct mechanisms of biofilm formation to interfere with phagocytosis and activation of mouse macrophage-like cells 774A.1. Infect Immun. 2011;79(6):2267-76.

35. Vuong C, Voyich JM, Fischer ER, Braughton KR, Whitney AR, DeLeo FR, Otto M. Polysaccharide intercellular adhesin (PIA) protects Staphylococcus epidermidis against major components of the human innate immune system. Cell Microbiol. 2004;6(3):269-75

36. Spiliopoulou Al, Krevvata MI, Kolonitsiou F, Harris LG, Wilkinson TS, Davies AP, Dimitracopoulos GO, Karamanos NK, Mack D, Anastassiou ED. An extracellular Staphylococcus epidermidis polysaccharide: relation to Polysaccharide Intercellular Adhesin and its implication in phagocytosis. BMC Microbiol. 2012;12:76

37. Gunther F, Wabnitz GH, Stroh P, Prior B, Obst U, Samstag Y, Wagner C, Hansch GM. Host defence against Staphylococcus aureus biofilms infection: phagocytosis of biofilms by polymorphonuclear neutrophils (PMN). Mol Immunol. 2009;46(8-9):1805-13.

38. Meyle E, Stroh P, Gunther F, Hoppy-Tichy T, Wagner C, Hansch GM. Destruction of bacterial biofilms by polymorphonuclear neutrophils: relative contribution of phagocytosis, DNA release, and degranulation. Int J Artif Organs. 2010;33(9):608-20

39. Stroh P, Gunther F, Meyle E, Prior B, Wagner C, Hansch GM. Host defence against Staphylococcus aureus biofilms by polymorphonuclear neutrophils: oxygen radical production but not phagocytosis depends on opsonisation with immunoglobulin G. Immunobiology. 2011;216(3):351-7.

40. Valour F, Trouillet-Assant S, Rasigade JP, Lustig S, Chanard E, Meugnier H, Tigaud S, Vandenesch F, Etienne J, Ferry T et al. Staphylococcus epidermidis in orthopedic device infections: the role of bacterial internalization in human osteoblasts and biofilm formation. PLoS One. 2013;8(6):e67240.

41. van der Flier M, Chhun N, Wizemann TM, Min J, McCarthy JB, Tuomanen El. Adherence of Streptococcus pneumoniae to immobilized fibronectin. Infect Immun. 1995;63(11):4317-22.

42. Dapunt U, Giese T, Maurer S, Stegmaier S, Prior B, Hansch GM, Gaida MM: Neutrophil-derived MRP-14 is up-regulated in infectious osteomyelitis and stimulates osteoclast generation. J Leukoc Biol. 2015;98(4):575-82.

43. Dapunt U, Maurer S, Giese T, Gaida MM, Hansch GM. The macrophage inflammatory proteins MIP1alpha (CCL3) and MIP2alpha (CXCL2) in implantassociated osteomyelitis: linking inflammation to bone degradation. Mediators Inflamm. 2014;2014:728619. 